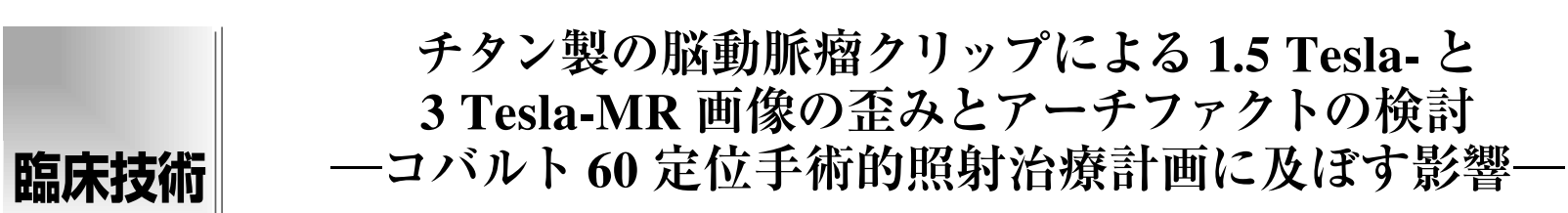

\author{
中澤寿人 ${ }^{1,2}$ 山室 修 $^{3}$ 内山幸男 $^{2}$ 小森雅孝 ${ }^{1}$ \\ ${ }^{1}$ 名古屋大学大学院医学系研究科 \\ 2 名古屋共立病院名古屋放射線外科センター \\ 3 東名古屋画像診断クリニック
}

\section{緒 言}

$3 \mathrm{~cm}$ 以下の頭蓋内病巣を対象とするガンマナイフ治 療では Leksell stereotactic skull frame(frame)を患者頭 部に装着して, magnetic resonance $(M R)$ 画像掞よび computed tomography $(\mathrm{CT})$ 画像を撮影し, 治療計画が 行われる. MR 画像は CT 画像と比較して, 組織間コン トラストが高く，造影剤の使用によって病巣の範囲を同 定しやすくなるが，磁場の不均一によって画像の歪みを 生じるため, CT 画像より幾何学的な位置精度は低い， 特に, frameを装着して撮影した MR 画像は CT 画像と
比較して最大で $0.8 \mathrm{~mm}$ の座標の変位を生じることが報 告されている ${ }^{1)}$ ，通常，治療計画では MR 画像と CT 画 像間の座標のずれが許容範囲内であることを確認して から MR 画像が単独で用いられる。

近年, 3 tesla $(\mathrm{T})$-MR 装置は広く普及し, 臨床で使用 されるようになった. 3 T-MR 画像は 1.5 T-MR 画像より 下垂体などのトルコ鞍周辺の微細解剖構造を良好に描 出できるが, $1.5 \mathrm{~T}$ より磁場不均一に敏感で, 画像歪み が生じやすい2．また， $3 \mathrm{~T}$ では検査時の安全性に関す る条件が厳しく，特に体内金属のある患者に対しては

\title{
Image Distortion and Artifacts Caused by the Use of a Titanium Aneurism Clip in 1.5 Tesla- and 3 Tesla-Magnetic Resonance Imaging: Effect on ${ }^{60}$ Cobalt Stereotactic Radiosurgery Treatment Planning
}

\author{
Hisato Nakazawa, ${ }^{1,2 *}$ Osamu Yamamuro, ${ }^{3}$ Yukio Uchiyama, ${ }^{2}$ and Masataka Komori ${ }^{1}$ \\ ${ }^{1}$ Department of Radiological Sciences, Nagoya University Graduate School of Medicine \\ ${ }^{2}$ Nagoya Radiosurgery Center, Nagoya Kyoritsu Hospital \\ ${ }^{3}$ Department of Imaging Technology, East Nagoya Imaging Diagnosis Center
}

Received November 27, 2013; Revision accepted April 19, 2014

Code No. 534

\section{Summary}

In gamma knife stereotactic radiosurgery (GKSRS) treatment planning, 1.5 tesla (T)-magnetic resonance imaging (MRI) is normally used to identify the target lesion. Image artifacts and distortion arise in MRI if a titanium clip is surgically implanted in the brain to treat cerebral aneurysm. 3-T MRI scanners, which are increasingly being adopted, provide imaging of anatomic structures with better clinical usefulness than 1.5-T MRI machines. We investigated signal defects and image distortions both close to and more distant from the titanium clip in 1.5-T and 3-T MRI. Two kinds of phantoms were scanned using 1.5-T and 3-T MRI. Acquisitions with and without the clip were performed under the same scan parameters. No difference was observed between $1.5 \mathrm{~T}$ and $3 \mathrm{~T}$ in local decrease of signal intensity; however, image distortion was observed at $20 \mathrm{~mm}$ from the clip in $3 \mathrm{~T}$. Over the whole region, the distortions caused by the clip were less than $0.3 \mathrm{~mm}$ and 1.6 mm under 1.5-T and 3-T MRI, respectively. The geometric accuracy of 1.5-T MRI was better than 3-T MRI and thus better for GKSRS treatment planning. 3-T MRI, however, appears less suitable for use in treatment planning.

Key words: stereotactic radiosurgery, treatment planning, magnetic resonance imaging (MRI), image distortion, metallic artifact

*Proceeding author 

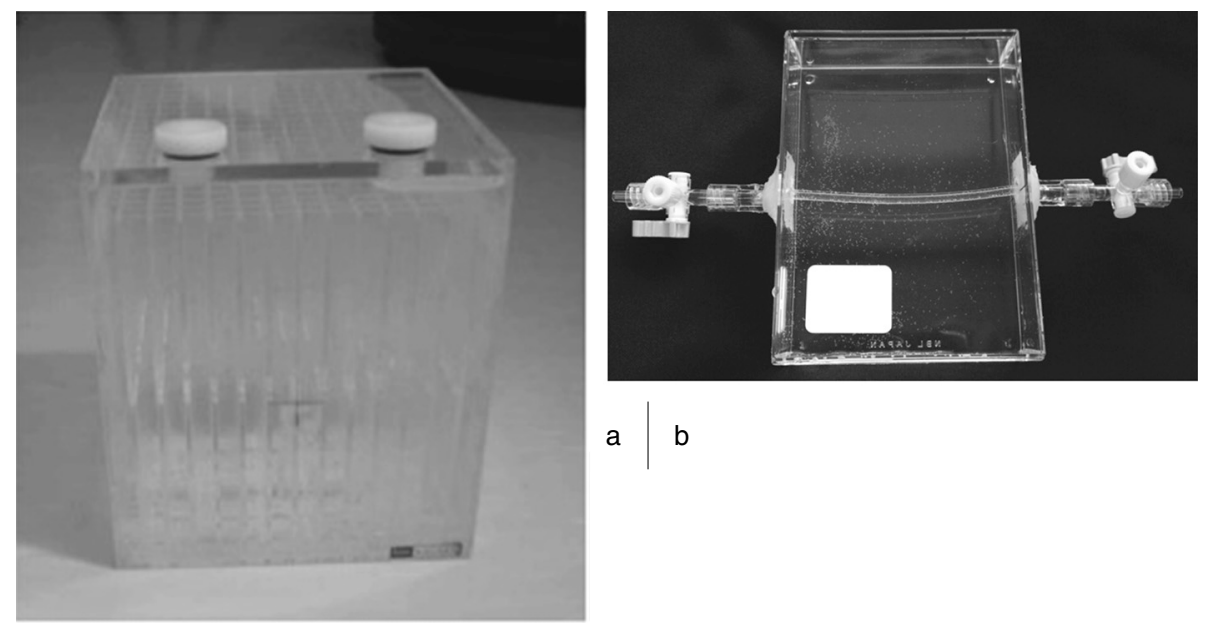

Fig. 1 Phantoms.

(a) Cube phantom

(b) Tube phantom

The spatial interval of the grid in the cube phantom is $1 \mathrm{~cm}$. The tube phantom comprises a structure passing a tube through a hole created at either end of the plastic case.

その素材と品番を調べ, 製造または販売元に検査が可 能か否かを問い合わせる必要がある。脳動脈瘤治療用 の金属製クリップが埋め込まれている場合, クリップの 安全性に加えて, クリップによって生じる信号欠損や画 像歪みを把握することが治療計画上で最も重要である。

脳動脈瘤のクリッピング術は脳動脈瘤治療全体の 80〜90\%を占めており，これまでに高い治療効果が報 告されている3). 従来はコバルト合金やステンレスなど がクリップの材質として使用されていたが, 静磁場の磁 力によってクリップが牽引, 脱落する危険性があるた め, 現在では撮影禁忌とされている ${ }^{4)}$. 近年はその影響 が少ないだけでなく, 軽く, 耐久性に優れる非磁性体 のチタンが利用されている。 これまでにチタンクリップ そのものが $1.5 \mathrm{~T}$ や $3 \mathrm{~T}$ の高磁場 MR 環境下で受ける 影響を調査した報告 5 , 6) やチタンクリップが 1.5 T-MR 画 像に及ぼす影響を画像診断の立場から定性的に調查し た報告》はあるが，ミリメートル以下の位置精度が要求 される放射線治療計画に利用することを想定して定量 的に評価した研究はない. 急峻な線量勾配を特徵とす るガンマナイフの線量分布はわずか $1 \mathrm{~mm}$ のずれによっ て大幅な線量変化を生じる。

本研究では, 1.5 T-, 3 T-MR 装置を用いて動脈㽣ク リップの近傍と動脈瘤クリップから離れた領域での画像 に及ぼす影響を定量的に評価した。画像歪みの評価は frameをファントムに装着して実際のガンマナイフ治療 を再現して行った。

\section{1. 対象・方法}

\section{1-1 使用機器}

MR 装置は GE 社製 Signa echo speed $1.5 \mathrm{~T}$ および Signa HDx 3 T を使用した. MR 撮像用ヘッドコイルは Quadrature $(\mathrm{QD})$ coil 使用した。治療計画装置は
ELEKTA 社製 Leksell GammaPlan(LGP) ver. 5.34, 画 像解析装置は GE 社製の Advantage work station ver. 4.02, フリーソフトゥエアの ImageJ ver. $1.43 \mathrm{u}(\mathrm{NIH})^{8}$, 頭蓋固定枠は ELEKTA 社製の Leksell stereotactic skull frame を使用した. ファントムはアクリル製で $1 \mathrm{~cm}$ 間隔 で格子状構造をもつ立方体ファントム(縦 $\times$ 横 $\times$ 高さ： $14 \mathrm{~cm} \times 14 \mathrm{~cm} \times 17 \mathrm{~cm}$ ) (Fig. 1a) と外径 $4 \mathrm{~mm}$, 内径 $2 \mathrm{~mm}$, 長さ $15 \mathrm{~cm}$ の雄・雄の成人用耐圧チューブ(ポリ塩化ビ ニル製)を縦 $\times$ 横 $\times$ 高さが $12 \mathrm{~cm} \times 9 \mathrm{~cm} \times 5 \mathrm{~cm}$ のプラス チック製ケース内に穴を開けて通し，三方活栓で蓋をし た自作のチューブファントム (Fig. 1b)を使用した．立方 体ファントム内を硫酸銅水溶液 $(0.002 \mathrm{mmol} / \mathrm{l})$, チュー ブファントムのアクリルケース内を生理食塩水, チュー ブ内を希釈した Gadolinium $(\mathrm{Gd})$ 造影剂溶液 $(0.1 \mathrm{mmol} / \mathrm{l})$ でそれぞれ満たした，チューブファントムはクリップに よる影響のみを評価するために立方体ファントムのよう に成人頭部の大きさと形状を模擬しなかった，動脈瘤 クリップは杉田チタンクリップ No. 07-934-10 standard typeを使用した。

\section{1-2 MR 画像の撮影条件}

MR 画像の撮影条件は当院でガンマナイフ治療計画 の時に使用している撮影条件を用いた. グラデイエント エコー系の $\mathrm{T}_{1}$ 強調画像である 3 dimensional-spoiled gradient recalled acquisition in the steady state(SPGR)を 横断面で撮影した. $1.5 \mathrm{~T}, 3 \mathrm{~T}$ では TEを除いて, 同じ 撮影条件を利用した. Echo time(TE)は装置ごとの最適 な条件としたため相違が生じた，撮像断面のエンコード 方向については周波数エンコード方向を左右方向に, 位相エンコード方向を前後方向に設定した．撮影条件 の詳細を Table 1 に示す．画像の座標系はX 軸を左右 方向 (右側を + ), $\mathrm{Y}$ 軸を前後方向 (前側を + ), $\mathrm{Z}$ 軸を頭 
Table 1 Detailed sequence parameter orders for 3D-SPGR with 1.5-T and 3-T MR imaging

\begin{tabular}{lcc}
\hline & \multicolumn{2}{c}{ 3D-SPGR } \\
\cline { 2 - 3 } & 1.5 tesla-MRI & 3 tesla-MRI \\
\hline Plane & axial & axial \\
Mode & $3 \mathrm{D}$ & $3 \mathrm{D}$ \\
TE (ms) & min full (5.06) & min full (3.2) \\
TR (ms) & 15 & 15 \\
ETL & 1 & 1 \\
Flip angle (deg) & 30 & 30 \\
Bandwidth (kHz) & 15.63 & 15.63 \\
NEX & 1 & 1 \\
FOV (cm) & 24 & 24 \\
Matrix size & $256 \times 256$ & $256 \times 256$ \\
Slice thickness (mm) & 1.0 & 1.0 \\
Number of slices & 190 & 190 \\
Scan time (min) & $8: 26$ & $8: 47$ \\
Imaging options & ZIP2 & ZIP2 \\
\hline
\end{tabular}

TE: echo time, TR: repetition time, ETL: echo train length, NEX: number of excitations, FOV: field of view, ZIP: zero full interpolation, SPGR: spoiled gradient recalled acquisition in the steady state

尾方向(頭側を+)と定義した

\section{1-3 検討項目}

1-3-1クリップ近傍における信号欠損領域および 画像歪みの範囲の検討

クリップ近傍の信号欠損領域の範囲と画像歪みの範 囲を評価するために，チューブファントムのチューブを クリップで固定したもの（Fig. 2a)としていないものをそ れぞれ 1.5 T-, 3 T-MR 装置で撮影した。ファントムは head コイル中心に配置し，チューブの横断像を撮影し た．信号強度の変化の大きさとその範囲を測定するた めに, ImageJを用いてファントム中心の横断面上で チューブの中心を通る水平ライン上のプロファイルカー ブを取得した，チューブが歪んでいる距離[真っ直ぐな チューブが真っ直ぐではない範囲の大きさ(頭尾方向)と チューブが本来あるべき位置から画像の歪みによって ずれが生じている距離(前後, 左右方向)]を撮影した画 像の X, Y, $\mathrm{Z}$ 軸の 3 方向で測定するためにワークス テーションで冠状断面と矢状断面に再構成した。測定 の不確かさを考慮するために, ファントムは 3 回撮影さ れ，それぞれの MR 画像の信号強度の平均值を測定值 とした。

\section{1-3-2 広範囲領域における歪みの影響}

クリップから $1 \mathrm{~cm}$ 以上離れた領域における画像歪み を測定するために，立方体ファントムに frame を装着
し，ファントム上にクリップを固定した状態(Fig. 2b， c) と何も置かない状態でそれぞれ 1.5 T-, 3 T-MR 画像を 横断面で撮影した，治療計画は通常，横断像で実施す るため，横断面上での変化のみを評価した，撮影の 際，座標系を設定するために reference マーカつきの fiducial box を frameに固定した(Fig. 2b)．撮影された 画像はLGPに転送され, reference マーカによって座標 系を決定した後に, クリップの有無による格子の位置座 標の変位を測定した，測定範囲はクリップから左右方 向に $\pm 6 \mathrm{~cm}$ の位置で, 深さ $10 \mathrm{~cm}$ まで $1 \mathrm{~cm}$ 間隔で位置 座標の変位を測定した. Fig. 2d に撮影した画像を示 す．格子は幅があるため，格子交点の右上角と左下角 の座標を取り，その中点を交点の座標とした，また，画 像の window level(WL), window width (WW)を変える と格子の幅が変化するため, 実際の格子の幅と画像上 の格子の幅が同じになるWLと WW の条件で測定し た，格子の中心位置測定は視覚評価による manual 計測 のため，不確かさを考慮してそれぞれの格子位置につ き異なる日に 3 回測定し, 平均值で評価した.

\section{2. 結 果}

2-1 クリップ近傍における信号欠損領域および画 像歪みの範囲の結果

Fig. 3 にクリップの有無によるチューブファントムの 横断像とプロファイルカーブを示す. Fig. 3a，d は $1.5 \mathrm{~T}$ でクリップのない場合とある場合に撮影した画像であ る. Fig. 3b，eは $3 \mathrm{~T}$ でクリップがない場合とある場合 に撮影した画像である.クリップ位置で信号欠損が観 察され，信号強度の低下を示した(Fig. 3f)，信号欠損の 範囲は両者ともほぼ同一であったが，その信号強度は $1.5 \mathrm{~T}$ の 401.8 に対して, $3 \mathrm{~T}$ では 426.4 と約 1.06 倍で あった.クリップなし(Fig. 3a， b)ではチューブ内の Gd 造影剤によって高信号が検出された(Fig. 3c)，クリップ がある場合でも信号欠損部内にわずかに信号増強部が 観察された(Fig. 3f)，Fig. 4 は Fig. 3d，e で示した横断 像を矢状断面と冠状断面に再構成した画像である. Fig. 4a，bはそれぞれ $1.5 \mathrm{~T}, 3 \mathrm{~T}$ の矢状断像である. Fig. $4 \mathrm{c}, \mathrm{d}$ はそれぞれ $1.5 \mathrm{~T}, 3 \mathrm{~T}$ の冠状断像である. $1.5 \mathrm{~T}$ の矢状断像ではクリップから頭尾方向 $10 \mathrm{~mm}$ 程 度にチューブの歪みが前後方向に $2 \mathrm{~mm}$ 程度観察され た。一方， $3 \mathrm{~T}$ の矢状断像ではクリップから頭尾方向 $20 \mathrm{~mm}$ 程度にチューブの歪みが前後 $4 \mathrm{~mm}$ 程度に観察 された(Fig. 4b)，冠状断像ではクリップ周囲の左右方向 に $1.5 \mathrm{~T}, 3 \mathrm{~T}$ 両者で $15 \mathrm{~mm}$ 程度のチューブの歪みが観 察された. 1.5 T-と 3 T-MR 画像におけるクリップによ る $\mathrm{X}, \mathrm{Y}, \mathrm{Z}$ 軸の 3 方向のチューブの歪みの大きさを 

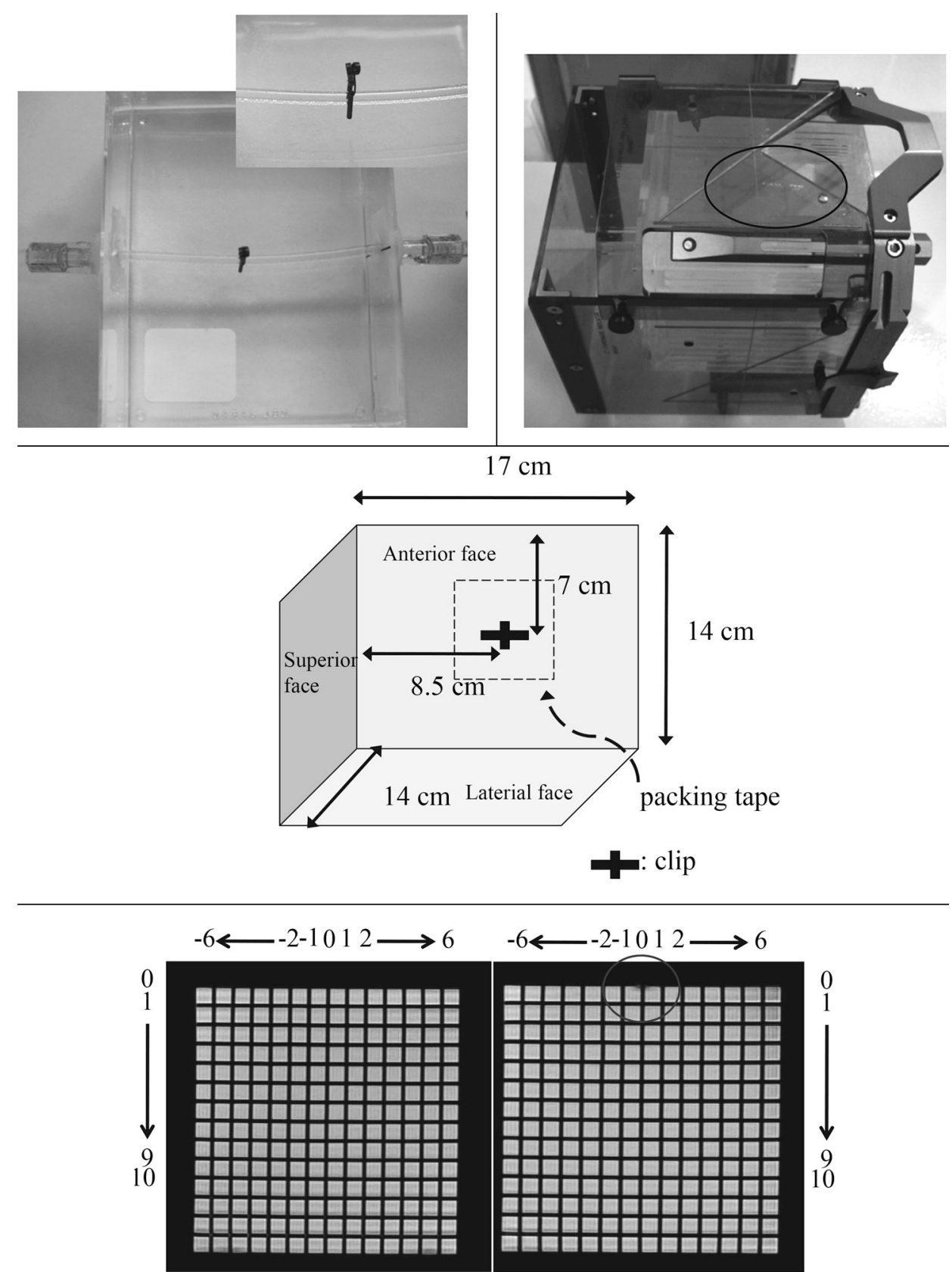

\section{Clip (-)}

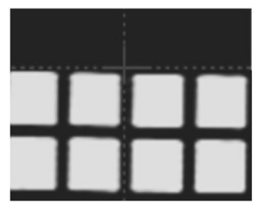

Clip (+)

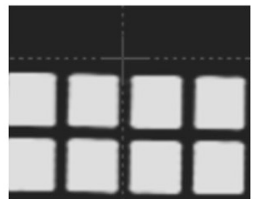

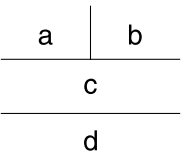

Fig. 2 Experimental configuration of phantoms.

(a) Aneurism clip clamped on tube phantom

(b) Aneurism clip placed on cube phantom attached to a stereotactic skull frame. Cube phantom attached to fiducial box with a reference marker. The black circle shows the clip position.

(c) Details of position of clip placed on cube phantom

(d) Discrepancy in positional coordinates of matrix structures with and without the clip. Measuring position ranged from $1-10 \mathrm{~cm}$ in depth at intervals of $1 \mathrm{~cm}$ right and left up to $6 \mathrm{~cm}$ from the clip position. 

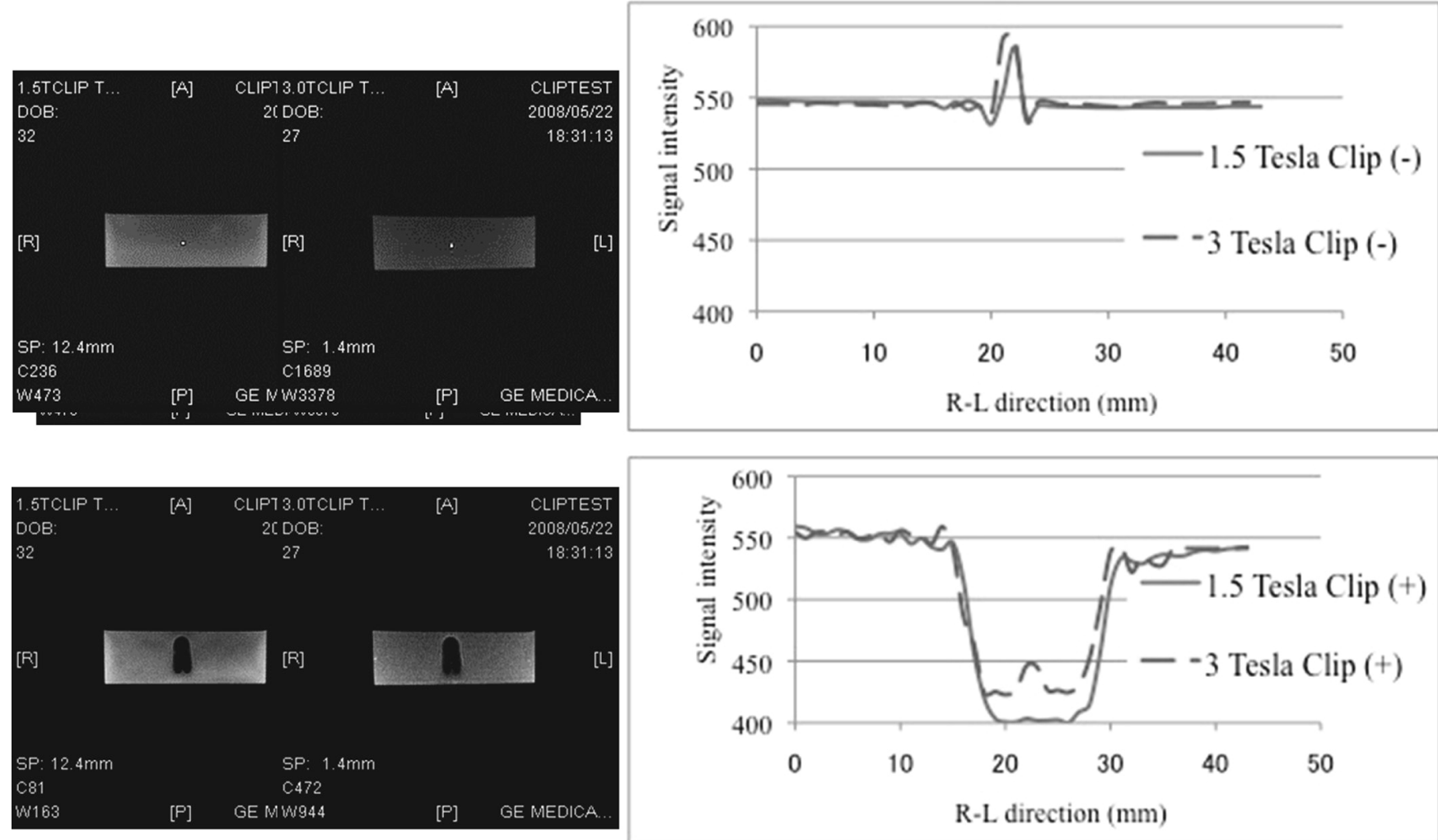

Fig. 3 Axial image and profile curve of tube phantom acquired using 1.5-T and 3-T MR scanners. Axial images acquired without (a) and with (d) aneurism clip at $1.5 \mathrm{~T}$. Axial images acquired without (b) and with (e) aneurism clip at $3 \mathrm{~T}$. Profile curves of without (c) and with (f) aneurism clip in $1.5 \mathrm{~T}$ and $3 \mathrm{~T}$. There was no difference in decrease of signal intensity in the clip position between $1.5 \mathrm{~T}$ and $3 \mathrm{~T}$.
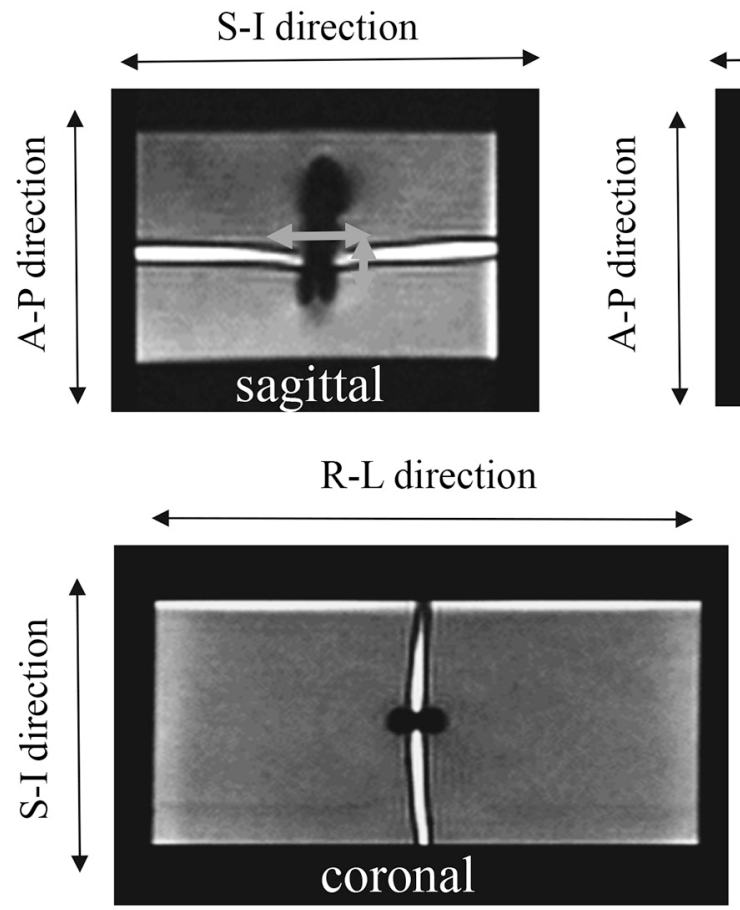
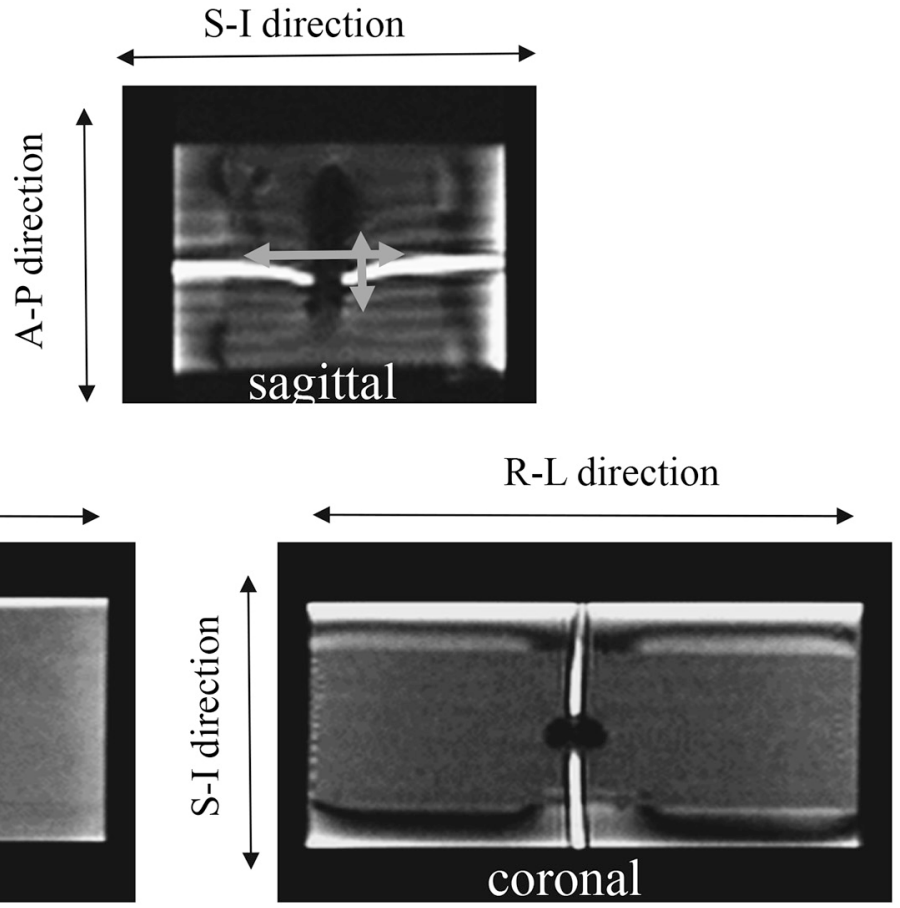

Fig. 4 Reconstructed sagittal and coronal image of tube phantom in 1.5-T and 3-T MR imaging. Gray arrow shows the distance of distorted tube $(a, b)$. Sagittal (a) and coronal (c) images at $1.5 \mathrm{~T}$. Sagittal (b) and coronal (d) images at $3 \mathrm{~T}$. Image distortion with width of $4 \mathrm{~mm}$ in anteriorposterior direction is observed around the aneurism clip (width of $20 \mathrm{~mm}$ in superior-inferior

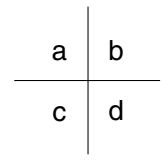
direction) (b). 
Table 2 Result of image distortions caused by aneurysm clip with 1.5-T and 3-T MR imaging

$(\mathrm{mm})$

\begin{tabular}{rccc}
\hline \hline & R-L direction & A-P direction & S-I direction \\
\hline 1.5 tesla-MRI & 15 & 2 & 10 \\
3 tesla-MRI & 15 & 4 & 20 \\
\hline
\end{tabular}
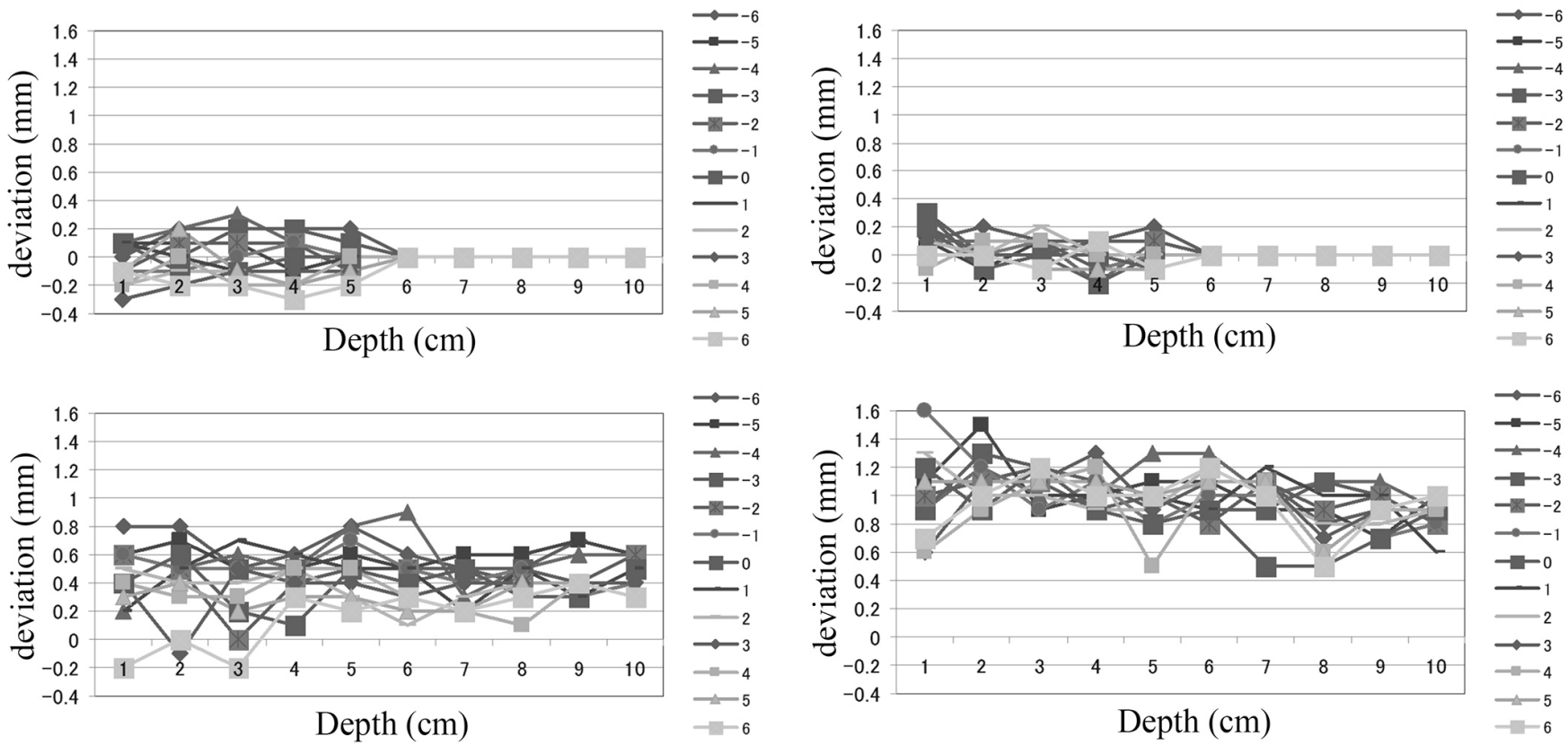

Fig. 5 Displacement of coordinates induced by using the aneurism clip with 1.5-T and 3-T MR imaging. Amount of displacement in the $\mathrm{x}(\mathrm{L}-\mathrm{R})$ and $\mathrm{y}(\mathrm{A}-\mathrm{P})$ directions with and without the clip at $1.5 \mathrm{~T}(\mathrm{a}, \mathrm{b})$. Amount of displacement in the $\mathrm{x}(\mathrm{L}-\mathrm{R})$ and $\mathrm{y}(\mathrm{A}-\mathrm{P})$ directions with and without the clip at $3 \mathrm{~T}(\mathrm{c}, \mathrm{d})$. Measuring position ranged from 1-10 cm in depth at intervals of $1 \mathrm{~cm}$ to right and left up to $6 \mathrm{~cm}$ from the clip position. The values (from -6 to +6 ) in the graph legend correspond to the measuring points presented in Fig. 2d.

Table 2 に示す.

\section{2-2＼cjkstart広範囲領域における歪みの影響の結果}

Fig. 5 にクリップの有無によるX，Y 方向の格子交点 の変位量を示した. クリップによる位置座標の変位は 1.5 T-MR 画像では X, Y 座標ともに深さ $5 \mathrm{~cm}$ までの範 囲で $0.3 \mathrm{~mm}$ 以内であり, 深さ $6 \mathrm{~cm}$ 以降では変位は観 察されなかったが(Fig. 5a, b)，3 T-MR 画像では深さ $10 \mathrm{~cm}$ まで位置座標の変位は観察され, $X$ 軸で最大 $0.9 \mathrm{~mm}, \mathrm{Y}$ 軸で最大 $1.6 \mathrm{~mm}$ であった(Fig. 5c, d).

\section{3. 考 察}

局所領域の影響について, クリップによる信号欠損 の広がりとその信号強度は $1.5 \mathrm{~T}, 3 \mathrm{~T}$ 両者でほぼ同程 度であったが, クリップによるチューブの頭尾方向およ び前後方向の歪みの大きさは $1.5 \mathrm{~T}$ と比較して, $3 \mathrm{~T}$ で
2 倍大きかった。広範囲領域の歪みの影響について, 画 像の歪みは $1.5 \mathrm{~T}, 3 \mathrm{~T}$ 両者でクリップ近傍で最大で あった. $1.5 \mathrm{~T}$ では深さ $5 \mathrm{~cm}$ までの範囲でクリップによ る歪みが $0.3 \mathrm{~mm}$ 以下であり, frame による最大 $0.8 \mathrm{~mm}$ の歪みを考慮しても $1 \mathrm{~mm}$ 以内に制限されるため, その まま治療計画に用いても問題ない。一方，3 Tではク リップによる歪みが深さ $10 \mathrm{~cm}$ まで観察され, $1.5 \mathrm{~T} よ$ り 3 から 5 倍程度も大きく, 最大で $1.6 \mathrm{~mm}$ であり, frameによる歪み(画像上の中心付近でも最大 $1.5 \mathrm{~mm}$ ) を考慮に入れると, 治療計画ではそれを満なす十分な マージンを取る必要がある。

信号欠損と画像歪みの大きさは金属の大きさと種 類, MR 画像の撮影条件に依存する。これまでの研究 で，加藤ら ${ }^{7)} 1.5 \mathrm{~T}-\mathrm{MR}$ 装置でチタン製クリップ (AESCULAP 社製)のほか, 材質の異なる数種類のク リップを撮影し, アーチファクト, 歪みを視覚評価し 
た. チタンクリップはステンレススチールやコバルト合 金製のクリップと比較して，アーチファクト，歪みがと もに大幅に改善され，画像診断にほとんど影響を与え ないと報告した。この結果は本研究の $1.5 \mathrm{~T} の$ 結果と同 様であった.

その他にも過去に MR 画像歪みに関する多くの研究 が行われており，撮像条件パラメー夕の調整9)，MR装 置に装備されたアプリケーションソフトによる画像処

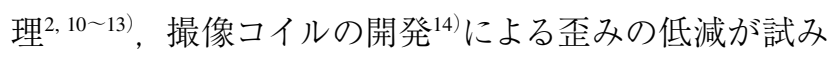
られている。しかし, 装置メーカの違いや装置にインス トールされている versionの違いによって，実際に利用 できない場合も多い．臨床的には施設ごとで，画質，歪 み，撮影時間を考慮した最適な撮影条件を構築するこ とが重要である，当院では，バンド幅を広げてエコー時 間とエコースペースを短縮し，磁場の不均一にさらされ る時間を短くして歪みの低減を図っている。その際に画 像の信号対雑音比が低くなるため, 加算回数を増やし て一定の画質になるように調整している.

われわれは治療計画用 MR 画像の撮影条件のコミッ ショニングテストで画質, 撮影時間を考慮した条件下で frame を装着したファントムを撮影し，歪みの大きさが 1 ピクセルサイズ $(1 \mathrm{~mm})$ 以下であることを確認して, 治療計画に利用している1．しかし，ガイドライン15)で は治療全体で $1 \mathrm{~mm}$ 以下の精度を要求している。武村 ら ${ }^{16)}$ は歪みによる $1 \mathrm{~mm}$ の誤差に加えて, 腫瘍範囲の同 定にばらつきがあるため，これらを考慮して planning target volume 設定時にマージンの追加を主張してい る。しかしながら，マージンは考慮されていないのが現 状である。

最近の治療計画装置には画像の重ね合わせ機能が具 備され, framelessの診断画像でも治療計画を作ること
ができる。しかし，重ね合わせをそのまま使用するので はなく，十分な検証が必要である。また，MR装置ス ペックの向上やアプリケーションソフトの開発によって 歪みの少ない, 良好な画質をもつ画像を提供できるよう になることが今後期待される。現時点では脳動脈瘤ク リップを埋め込んだ症例に frameを装着して撮影した 3 T-MR 画像を治療計画に利用するには克服すべき課題 が残る.

\section{4. 結 語}

1.5 T-MR 画像と比較して組織解像度の高い 3 T-MR 画像は, 頭蓋底や下垂体近傍などの複雑な微小解剖構 造を詳細に描出することができる。しかし，近接する Willis 動脈輪に動脈瘤クリップが使用されている場合, 画像の幾何学的な精度は低下している可能性がある. 本研究では，2 種類のファントムを用いて 1.5 T-MR 画 像と 3 T-MR 画像におけるチタン製クリップによるアー チファクトと画像歪みをクリップの近傍の局所領域とク リップから離れた広範囲領域で評価した。 $3 \mathrm{~T}$ では局所 領域で最大 $4 \mathrm{~mm}$ の画像歪みを生じ,ささらにの影 響はクリップ周囲 $6 \mathrm{~cm}$, 深さ $10 \mathrm{~cm}$ の広範囲領域に わたって，平均で約 $1 \mathrm{~mm}$ の画像歪みをもたらした。 3 T-MR 画像をガンマナイフ治療計画に使用する際, 動 脈瘤クリップの安全性が補償されていても, 現時点で の使用は克服すべき課題があり，困難であると考えら れる。

\section{謝 辞}

本研究にご協力いただいた，名古屋共立病院名古屋 放射線外科センタースタッフおよび同院医療技術部画 像技術課諸氏に深く感謝致します。 


\section{参考文献}

1) Mori Y, Hayashi N, Iwase M, et al. Stereotactic imaging for radiosurgery: localization accuracy of magnetic resonance imaging and positron emission tomography compared with computed tomography. Stereotact Funct Neurosurg 2006; 84(4): 142-146.

2) Watanabe $Y$, Lee CK, Gerbi BJ. Geometrical accuracy of a 3-tesla magnetic resonance imaging unit in Gamma Knife surgery. J Neurosurg 2006; 105(Suppl): 190-193.

3）中村一仁, 石黒友也, 池田英敏, 他. 未破裂脳動脈瘤ク リッピング術の治療成績－脳動脈瘤手術初心者の経験一. 脳卒中の外科 $2007 ; 35(5): 370-375$.

4）宮地利明. MRI の安全性. 日放技学誌 2003; 59(12): 15081516.

5) Cheung JY, Yu KN, Chan JF, et al. Dose distribution close to metal implants in Gamma Knife Radiosurgery: a Monte Carlo study. Med Phys 2003; 30(7): 1812-1815.

6) Cheung JY, Yu KN. Dose distribution close to metal implants in gamma knife radiosurgery: a Monte Carlo study. Med Phys 2005; 32(5): 1448-1449.

7）加藤庸子, 佐野公俊, 二宮 敬, 他. 新チタン製脳動脈瘤 クリップの臨床経験 - CT, MRIに及ぼす影響一。脳神経外 科ジャーナル 1995; 4(6): 588-592.

8）中島正弘. パーソナルコンピュータを用いた医用画像処理の 基礎 - Image J を用いて DR 画像編一。 日放技学誌 2009; 65(11): 1568-1571.

9) Zhang B, MacFadden D, Damyanovich AZ, et al. Development of a geometrically accurate imaging protocol at 3 Tesla MRI for stereotactic radiosurgery treatment planning.
Phys Med Biol 2010; 55(22): 6601-6615.

10) Sumanaweera T, Glover G, Song S, et al. Quantifying MRI geometric distortion in tissue. Magn Reson Med 1994; 31(1): 40-47.

11) Tanner SF, Finnigan DJ, Khoo VS, et al. Radiotherapy planning of the pelvis using distortion corrected MR images: the removal of system distortions. Phys Med Biol 2000; 45(8): 2117-2132.

12) Reinsberg SA, Doran SJ, Charles-Edwards EM, et al. A complete distortion correction for MR images: II. Rectification of static-field inhomogeneities by similarity-based profile mapping. Phys Med Biol 2005; 50(11): 2651-2661.

13) Karger CP, Hoss A, Bendl R et al. Accuracy of device-specific $2 \mathrm{D}$ and $3 \mathrm{D}$ image distortion correction algorithms for magnetic resonance imaging of the head provided by a manufacturer. Phys Med Biol 2006; 51: 253-261.

14) Jursinic P, Prost R, Schultz C. A new magnetic resonance head coil and head immobilization device for gamma knife radiosurgery: an analysis of geometric distortion and signal/ noise characteristics. J Neurosurg 2002; 97(Suppl 5): 563568.

15）白太博樹．定位放射線治療の品質管理一頭部一，放射線治 療計画ガイドライン 2008. メデイカル教育研究社, 埼玉, 2008: 12-14.

16）武村哲浩, 笹本耕平, 仲村香織, 他. 静磁場強度の異なる 3 機種を用いた脳定位放射線治療計画のための MRI 画像の 歪み比較. 日放技学誌 2013; 69(6): 641-647. 